\title{
DAYA DUKUNG LINGKUNGAN DALAM PENGEMBANGAN PUSAT INOVASI USAHA MIKRO, KECIL, DAN MENENGAH (PI-UMKM) PETERNAKAN DOMBA- KAMBING DI KABUPATEN PANDEGLANG PROVINSI BANTEN
}

\section{ENVIRONMENT CARRYING CAPACITY IN DEVELOPING INNOVATION CENTER OF MICRO SMALL MEDIUM ENTREPRISES (MSME) IN KABUPATEN PANDEGLANG, BANTEN PROVINCE}

\author{
Muhlisin, Suroso Mukti Leksono, dan Devi Triady Bahrudin \\ Badan Penelitian dan Pengembangan Provinsi Banten \\ KP3B Jl. Syeh Nawawi Al-Bantani, Palima Serang-Banten 42171 \\ Email: muhlisinsidik@gmail.com \\ Dikirim: Direvisi: Disetujui:
}

\begin{abstract}
Abstrak
Penelitian ini bertujuan untuk mengetahui Daya Dukung Lingkungan (DDL) dan strategi dalam Pengembangan PI-UMKM Peternakan Domba dan Kambing Kelurahan Juhut, Kabupaten Pandeglang. Penelitian menggunakan metode deskriptif kuantitatif dengan instrumen kuesioner yang diberikan kepada stakeholder serta pemerintah yang berkaitan dengan peternakan domba dan kambing di Kelurahan Juhut Pandeglang. Data yang terkumpul diolah denga penskoran dan Analitical Hierarchy Process (AHP) menggunakan software expert choice 11. Hasil penelitian menunjukkan bahwa tingkat DDL PI-UMKM berada pada katagori cukup, dengan variabel yang berproporsi paling tinggi adalah aspek fasilitasi dan yang terrendah pada aspek akses informasi. Strategi pengembangan PI-UMKM adalah melalui upaya peningkataan variabelvariabel yang mempengaruhi DDL dalam pengembangan PI-UMKM yang masih kurang atau belum memenuhi standar melalui usaha sinergi Kemenristek dan Dikti, Pemrov. Banten, Pemkab/Pemkot, BPTP, dan Perguruan Tinggi.

Kata kunci: Pusat inovasi, UMKM, peternakan domba dan kambing.
\end{abstract}

\begin{abstract}
The study aims to determine environmental carrying capacity strategies for developing MSMEs Innovation Center. The study research using quantitative descriptive method and instruments questionnaire given to stakeholders and government related to sheep and goats in the Juhut village, Pandeglang. Data collected was processed premises scoring and Analitical Hierarchy Process (AHP) method used software of expert choice 11. The results showed that the Caryng Capacity levels of MSME was in the quite category, while aspect of facilitation as the highest proportions and the lowest was access to information. Innovation Center of MSME strategies are through the efforts increased Environment Carrying Capacity's variables of Innovation Center of MSME are still lacking or not meet the standards through synergy efforts by Ministry of Research of Technology and Higher Education, Provincial Government. Of Banten, district/municipal government, Institute for Agricultural Technology of Banten, and universities.

Keywords: Innovation centre, small medium enterprises, sheep and goat farm.
\end{abstract}

\section{PENDAHULUAN}

Propinsi Banten terbentuk dari pemekaran Propinsi Jawa Barat melalui Undang-Undang Republik Indonesia Nomor 23 Tahun 2000 dengan salah satu tujuannya adalah untuk meningkatkan kesejahteraan rakyat di Banten. Hal ini diperkuat dengan amanah UU No 32 tahun 2004, tentang otonomi daerah, disebutkan bahwa tujuan otonomi daerah adalah untuk meningkatkan kesejahteraan masyarakat, pelayanan umum, dan daya saing daerah. Potensi Banten sangat banyak yang belum dikembangkan, antara lain sumber daya `alam, potensi pertanian, peternakan dan kelautan serta potensi sumber daya manusianya.

Salah satu cara untuk mengembangkan potensi yang dimiliki oleh Propinsi Banten guna meningkatkan kesejahteraannya adalah dibentuknya Unit usaha kecil dan menengah (UKM). UKM-UKM yang telah terbentuk perlu ditingkatkan daya saingnya melalui inovasi-inovasi, sehingga perlu dibentuk Pusat Inovasi UMKM (PI UMKM). Kepala daerah serta wakil kepala daerah menjadi penanggungjawabnya. Salah satu wujud tanggungjawab tersebut secara eksplisit adalah mengembangkan pusat inovasi usaha kecil menengah dan mikro.

PI UMKM adalah Pusat Inovasi Usaha Mikro, Kecil dan Menengah, yaitu suatu organisasi atau unit organisasi sebagai simpul dari jaringan kemitraan yang memberikan jasa pelayanan terpadu untuk menumbuhkembangkan UMKM yang inovatif. Jasa layanan PI UMKM yang diberikan kepada UMKM dapat berupa layanan teknologi, pengembangan sumber daya manusia (SDM), intermediasi bisnis, 
inkubasi bisnis, akses informasi bisnis, maupun fasilitasi akses pembiayaan bisnis (Subagjo, 2011).

Lebih lanjut Subagjo (2011), mengemukakan bahwa PI UMKM sebagai salah satu elemen pendukung Sistem Inovasi Daerah berposisi sebagai pendukung dan pemerkuat elemen "bisnis" di dalam Kerangka Elemen Pengembangan Sistem Inovasi Daerah. Di dalam kerangka tersebut, PI UMKM berperan sebagai simpul dari suatu jaringan kemitraan yang memberikan jasa pelayanan terpadu untuk menumbuhkembangkan UMKM inovatif baik melalui peningkatan kinerja UMKM yang telah ada maupun penumbuhkembangan UMKM baru yang inovatif. Jasa layanan terpadu yang dapat diberikan PI UMKM antara lain meliputi:

1). Jasa layanan berbasis teknologi,

2). Pengembangan SDM UMKM,

3). Intermediasi bisnis UMKM, dan

4). Fasilitasi akses pembiayaan bisnis.

Propinsi Banten telah mempunyai beberapa UKM diantaranya adalah pengembangan domba dan kambing Kampung Juhut, rumput laut dan budidaya melon. UKM-UKM tersebut berperan dalam penyerapan tenaga kerja dan menyumbang pertumbuhan perekonomian daerah. Dari beberapa UKM yang ada tersebut pengembangan Peternakan Domba dan Kambing Kampung Juhut sangat potensial untuk ditindak lanjuti, sebab memiliki potensi dalam penyerapan tenaga kerja, sumbangan terhadap perekonomian, ketersediaan bahan baku, dapat diperbaharui atau berkelanjutan, ketersediaan pasar dan dan adanya regulasi yang jelas (Oktaviana, dkk., 2014). Untuk mengembangkan usaha peternakan domba dan kambing di Juhut perlu dibentuk Pusat Inovasi Peternakan Domba dan Kambing Kampung Juhut. PI UMKM Dombing Juhut diperlukan untuk dapat memodernisasi usaha kecil yang meliputi kemampuan pengusaha, ketrampilan pekerja, sistem manajemen termasuk model bisnis, dan memperkuat peningkatan daya serap teknologi karena teknologi merupakan pemicu nilai tambah. Selain itu PI UMKM juga berperan dalam peningkatan difusi inovasi, pengembangan SDM. dinamisasi perkembangan inovasi, bisnis dan manajemen.

Pengembangan Pusat Inovasi UMKM Domba/Kambing di Kelurahan Juhut perlu memperhatikan daya dukung lingkungannya. Secara konseptual daya dukung lingkungan hidup menurut UU No. 23 tahun 1997 adalah kemampuan lingkungan hidup untuk mendukung perikehidupan manusia dan makhluk hidup lain. Daya dukung lingkungan adalah kapasitas atau kemampuan ekosistem untuk mendukung kehidupan organisme secara sehat sekaligus mempertahankan produktivitas, kemampuan adaptasi, dan kemampuan memperbarui diri.

Irwan (1997), juga menyatakan bahwa daya dukung lingkungan diartikan sebagai kemampuan lingkungan untuk mendukung kehidupan manusia. Daya dukung lingkungan (carrying capacity) juga artikan sebagai batas atas dari pertumbuhan suatu populasi, dimana jumlah populasi tersebut tidak dapat lagi didukung oleh sarana, sumberdaya dan lingkungan yang ada. Secara lebih singkat dapat dijelaskan sebagai batas aktivitas manusia yang berperan dalam perubahan lingkungan. Konsep ini berasumsi bahwa terdapat kapastian keterbatasan lingkungan yang bertumpu pada pembangunan.

Bila dikaitkan dengan PI UMKM, daya dukung lingkungan diartikan dengan kemampuana lingkungan untuk mendukung pengembangan Pusat Inovasi UMKM yang indikatornya adalah: identifikasi layanan teknologi, sumber daya manusia, daya dukung inkubasi bisnis, fasilitasi dan akses informasi (Taufik, 2007; Susilo, 2010; dan Subagjo, 2010). Identifikasi daya dukung lingkungan PI UMKM domba/kambing di keluruahan Juhut penting dilakukan untuk mengembangkan Sistem inovasi daerah di Provinsi Banten.

Berdasarkan latar belakang tersebut, perlu dilakukan penelitian yang memfokuskan pada: tingkat daya dukung lingkungan peternakan domba dan kambing kampung juhut, identifikasi variabel daya dukung lingkungan yang sudah siap dalam pengembangan Pusat Inovasi UMKM peternakan domba dan kambing kampung juhut, dan mendeskripsikan strategi pengembangan pusat inovasi UMKM peternakan domba dan kambing kampung juhut.

Ruang lingkup kajian ini adalah adanya kebutuhan pengembangan PI UMKM sebagai sarana untuk mengembangankan UMKM Peternakan DombaKambing Kelurahan Juhut di Provinsi Banten. Pengembangan PI UMKM diperlukan untuk memberikan layanan teknologi, pengembangan sumber daya manusia (SDM), intermediasi bisnis, inkubasi bisnis, akses informasi bisnis, maupun fasilitasi.

Untuk mengetahui daya dukung lingkungan UMKM Peternakan Domba-Kambing dalam mendukung pengebangan PI UMKM, dilakukan analisis daya dukung lingkungan fisik dengan mempertimbangkan potensi Peternakan DombaKambing Desa Juhut di Provinsi Banten. Secara skematik kerangka pemikiran dijelaskan oleh Gambar 1 .

\section{METODE}

Penelitian ini menggunakan metode deskriptif kuantitatif. Pengumpulan informasi tentang potensi pengembangan PI-UMKM peternakan domba-kambing di Provinsi Banten dilakukan melalui kuesioner. Populasi penelitian ini untuk daya dukung lingkungan peternakan domba-kambing Juhut adalah para pelaku dan pemangku kebijakan yang berkaitan dengan peternakan domba-kambing Juhut baik pemerintah maupun masyarakat. Sedangkan sampelnya adalah Pemerintah Kabupaten Pandeglang yang meliputi: Bappeda, Dinas Peternakan dan Kesehatan Hewan, dan Dinas Koperasi UMKM; Pemerintah Provinsi Banten yang terdiri dari: Dinas Pertanian dan Peternakan, Dinas Koperasi dan UMKM, dan Balitbangda; Perguruan Tinggi meliputi Fakultas Ekonomi dan Fakultas Pertanian Unirta dan STISIP Banten Raya; 
serta Instansi vertikal Balai Pengkajian Teknologi Pertanian Banten (BPTP Banten).

diberikan empat pilihan jawaban dan satu jawaban terbuka.

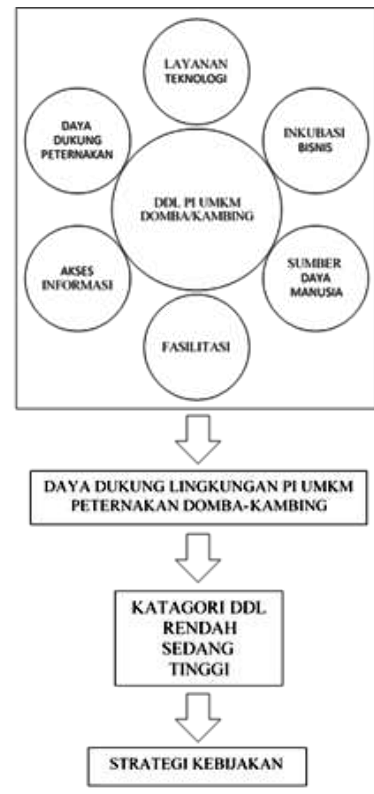

Gambar 1. Kerangka Pemikiran Penelitian Daya Dukung Lingkungan Peternakan Domba-Kambing di Provinsi Banten

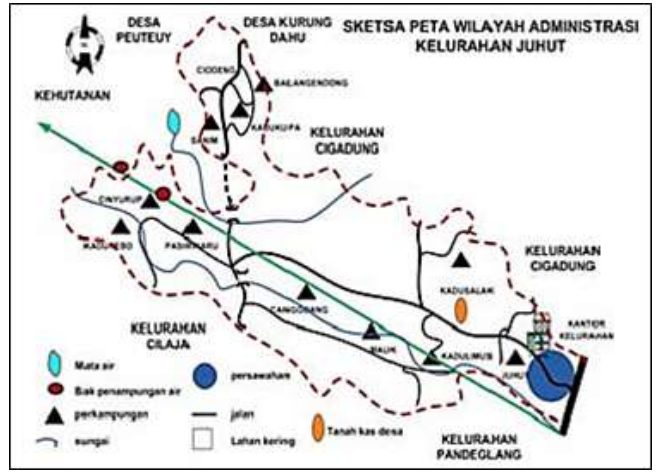

Sumber: Sinar Tani, 2011

Gambar 2. Peta Lokasi Peternakan Domba-Kambing.Kelurahan Juhut, Kab. Pandeglang

Pengambilan data penelitian PI-UMKM dilakukan di Kelurahan Juhut Pandeglang, Pemerintah Kab. Pandeglang, dan Pemerintah Prov. Banten pada bulang Oktober-November 2014.

Langkah pertama yang harus dilakukan dalam penentuan daya dukung lingkungan PI-UMKM adalah menentukan variabel-variabel penentu yang mendukung pengembangan PI-UMKM. Berikutnya menentukan indikator-indikator yang menentukan variabel penentu pengembangan PI-UMKM.

Indikator-indikator yang menentukan daya dukung lingkungan PI-UMKM disajikan pada Tabel 1.

Berdasarkan indikator yang telah ditentukan, kemudian disusun instrumen yang terdiri dari 25 pertanyaan yang mengacu pada indikator variabel daya dukung lingkungan. Setiap pertanyaan terdiri dari dua pilihan utama, "Ya" dan "Tidak". Bila menjawab "Ya"
Untuk variabel dan indikator daya dukung lingkungan peternakan domba-kambing Juhut disajikan pada Tabel 2.

Untuk kuesioner daya dukung lingkungan fisik, sosial ekonomi, dan ekologi, terdiri dari 15 pernyataan sesuai indikator. Hal yang sama seperti pada kusioner daya dukung lingkungan PI-UMKM, setiap pernyataan ada dua alternatif jawaban "Ya" dan "Tidak", dengan empat alternatif jawaban tertutup dan satu jawaban terbuka bila responden menjawab "Ya"

Untuk mengetahui tingkat daya dukung lingkungan peternakan domba-kambing Juhut dan PIUMKM Peternakan domba-kambing Juhut dilakukan melalui penskoran. Skor 1 untuk Jawaban "Tidak" dan skor 2-10 untuk jawaban "Ya" sesuai jumlah jawaban atau tingkatannya. Berdasarkan perhitungan persentil diketahui kriteria untuk daya dukung lingkungan 
peternakan dan PI UMKM adalah: kurang (1-83), cukup (84-166), dan baik (167-250). process) dan metode pairwaise individual (dari software expert choice 11).

Tabel 1. Indikator Daya Dukung Lingkungan PI-UMKM Peternakan Domba-Kambing Juhut

\begin{tabular}{|c|c|}
\hline Variabel Daya & Indikator \\
\hline Identifikasi Layanan & 1. Akses info Teknologi \\
\hline Teknologi & 2. Akses informasi HKI, \\
\hline & 3. Mempertemukan inventor dengan UMKM, \\
\hline & 4. Bantuan teknis ke UMKM, dan \\
\hline & 5. Konsultasi Layanan Teknologi \\
\hline Sumber Daya Manusia & 1. Penyuluh \\
\hline & 2. Peneliti \\
\hline & 3. Konsultan bisnis \\
\hline & 4. Konsultan Marketing \\
\hline & 5. Ahli bidang Peternakan Domba/Kambing \\
\hline Daya Dukung & 1. Space \\
\hline Inkubasi Bisnis & $\begin{array}{l}\text { 2. Service \& Skill Development } \\
\text { 3. Support: } \\
\text { 4. Seed Capital: } \\
\text { 5. Sinergy: }\end{array}$ \\
\hline Fasilitasi & $\begin{array}{l}\text { 1. Informasi sumber-sumber pembiayaan, } \\
\text { 2. menghubungkan UMKM dengan sumber pembiayaan, } \\
\text { 3. memberi akses info pasar, } \\
\text { 4. klinik konsultasi bisnis } \\
\text { 5. promosi produk UMKM }\end{array}$ \\
\hline Akses Informasi & $\begin{array}{l}\text { 1. Layanan Informasi } \\
\text { 2. Publikasi, } \\
\text { 3. Sumber Informasi } \\
\text { 4. Website } \\
\text { 5. Mobile information }\end{array}$ \\
\hline
\end{tabular}

Sumber: Modifikasi dari Taufik (2013); Susilo (2010); dan Subagjo (2010)

Tabel 2. Indikator Daya Dukung Lingkungan Peternakan Domba-Kambing Kelurahan Juhut

\begin{tabular}{ll}
\hline \multicolumn{1}{c}{$\begin{array}{c}\text { Variabel Daya Dukung } \\
\text { Lingkungan }\end{array}$} & \multicolumn{1}{c}{ Indikator } \\
\hline Daya Dukung Fisik & 1. Aspek Jalan \\
& 2. Sumber Listrik \\
& 3. Sumber Air Bersih \\
& 4. Drainase \\
& 5. Telekomunikasi \\
Daya Dukung Sosial Ekonomi & 1. Pekerjaan Penduduk \\
& 2. Pendapatatan Rata-rata \\
& 3. Ketersediaan tenaga \\
& 4. Derja \\
Daya Dukung Ekologis & 5. Kelompok Tani \\
& 1. Penggunaan Lahan \\
& 2. Pasokan Air \\
& 3. Ketersediaan Pakan \\
& 4. Ketersediaan Kandang \\
& 5. Layanan Kesehatan \\
\hline
\end{tabular}

Sementara itu, penentuan tingkatan variabel daya dukung lingkungan yang sudah memenuhi dilakukan dengan memberikan penilaian atau bobot menggunakan analisis AHP (analytical hierarchy
Pendekatan AHP menggunakan skala Saaty (1994) seperti yang terlihat pada Tabel 3, mulai dari nilai bobot 1 sampai 9. Nilai bobot 1 menggambarkan "sama penting". Ini berarti bahwa nilai atribut yang sama skalanya, nilai bobotnya 1 , sedangkan nilai bobot 
9 menggambarkan kasus atribut yang "penting absolut" dibandingkan dengan yang lainnya. usaha konservasi dan keterkaitan usahatani (integrasi tanaman-ternak). Oleh karena itu upaya rehabilitasi

Tabel 3. Skala Banding secara Berpasangan

\begin{tabular}{|c|c|c|}
\hline $\begin{array}{l}\text { Tingkat } \\
\text { Kepenting- } \\
\text { an } \\
\end{array}$ & Definisi & Penjelasan \\
\hline 1 & Kedua elemen sama penting & $\begin{array}{l}\text { Dua elemen mempunyai pengaruh } \\
\text { yang }\end{array}$ \\
\hline 3 & $\begin{array}{l}\text { Elemen yang satu sedikit } \\
\text { lebih penting daripada elemen } \\
\text { yang lain }\end{array}$ & sama besar terhadap tujuan \\
\hline 5 & $\begin{array}{l}\text { Elemen yang satu lebih } \\
\text { penting daripada elemen yang } \\
\text { lain }\end{array}$ & $\begin{array}{l}\text { Pengalaman dan penilaian sedikit } \\
\text { mendukung satu }\end{array}$ \\
\hline 7 & $\begin{array}{l}\text { Satu elemen jelas lebih } \\
\text { penting daripada elemen } \\
\text { lainnya }\end{array}$ & $\begin{array}{l}\text { elemen dibanding elemen yang } \\
\text { lainnya }\end{array}$ \\
\hline 9 & $\begin{array}{l}\text { Satu elemen mutlak lebih } \\
\text { penting daripada elemen yang } \\
\text { lainnya }\end{array}$ & $\begin{array}{l}\text { Pengalaman dan penilaian sangat kuat } \\
\text { mendukung }\end{array}$ \\
\hline $2,4,6,8$ & Nilai-nilai antara dua nilai & $\begin{array}{l}\text { satu elemen dibanding elemen yang } \\
\text { lainnya }\end{array}$ \\
\hline Kebalikan & $\begin{array}{l}\text { pertimbangan yang } \\
\text { berdekatan }\end{array}$ & $\begin{array}{l}\text { Satu elemen dengan kuat didukung } \\
\text { dan dominan }\end{array}$ \\
\hline
\end{tabular}

Sumber: Saaty (1994)

Dari hasil analisis akan diketahui variabel mana yang memiliki daya dukung lingkungan yang paling tinggi, juga dapat diketahui instansi mana yang paling siap untuk mendukung pengembangan PI-UMKM.

\section{HASIL DAN PEMBAHASAN}

\section{Deskripsi Lokasi Peternakan Domba-Kambing Kelurahan Juhut \\ Kampung Domba Terpadu (KDT) berada di kampung} Cinyurup, Kelurahan Juhut, Kecamatan Karang Tanjung, Kabupaten Pandeglang, Provinsi Banten. Kelurahan Juhut yang digolongkan sebagai desa "swasembada" berada di kawasan hutan lindung lereng Gunung Karang dengan ketinggian 250-700m diatas permukaan laut, luas 387 ha, dibagi kedalam $6 \mathrm{RW} / 28$ RT, 1383 KK dengan jumlah penduduk sebanyak 6191 orang. Sebagian besar wilayah bertopografi miring/lereng, dengan curah hujan sekitar 2000 $\mathrm{mm} /$ tahun, dengan iklim tipe B1 (klasifikasi Oldeman). Tingkat pendidikan masyarakat masih rendah dengan mata pencaharian penduduk $41 \%$ sebagai tukang, $24 \%$ buruh tani, $13 \%$ petani pemilik, dan selebihnya sebagai pegawai, buruh kasar, dan pedagang (Balitnak, 2011)

Kampung Ternak Domba terletak di Kampung Cinyurup, Kelurahan Juhut, Kecamatan Karang Tanjung, Kabupaten Pandeglang, Propinsi Banten dibentuk sebagai Buffer Zone (kawasan penyangga) karena lokasi tersebut berbatasan dengan kawasan hutan lindung yang dapat menyediakan ketersediaan rumput lapangan dan leguminosa pohon sepanjang tahun dengan kualitas yang baik. Pola pikir yang dikembangkan adalah dengan memberdaya-kan masyarakat sekitar hutan melalui usaha pemeliharaan ternak domba, maka usahatani sayuran yang banyak merambah hutan sekitar dapat dikendalikan melalui hutan lindung, dan diversifikasi ataupun pengalihan prioritas usaha dari menanam sayuran di kawasan hutan menjadi usahatani ternak terpadu menjadi salah satu sasaran yang hendak dicapai, di samping upaya peningkatan pendapatan petani (Sinar Tani, 2011)

Bibit ternak domba yang diharapkan mampu berkembang adalah bibit ternak unggul dari teknologi kawin silang yang dilakukan oleh para pakar pemulia Balitnak dan telah diintroduksikan ke dalam kawasan kampung ternak sejak pembentukannya. Bibit unggul yang dimaksud adalah domba komposit Sumatera yang merupakan hasil persilangan antara domba Barbados Blackbelly (25\%), St. Croix (25\%) dan 50\% lokal Sumatera, dengan keunggulan: mempunyai daya adaptasi lebih tinggi di daerah tropis, pertumbuhan lebih cepat, lebih tahan terhadap penyakit cacing (Haemonchus sp. dan Fasciola sp.), mempunyai sifat prolifik seperti domba lokal, dan siklus reproduksi tidak dipengaruhi oleh musim.

Ternak domba lain yang juga diintroduksikan adalah domba komposit Garut hasil persilangan 25\% Moulton Charalois, 25\% St. Croix, dan 50\% lokal Garut, dengan keunggulan memiliki daya adaptasi lebih tinggi di daerah tropis, pertumbuhan lebih cepat, mempunyai jumlah anak sekelahiran sama dengan domba lokal, dan mampu melahirkan sepanjang tahun Selain itu, telah diintroduksikan juga ternak Domba Barbados Cross yang merupakan persilangan antara domba Barbados dengan domba lokal, yang diharapkan mempunyai daya adaptasi lebih baik dengan lingkungan Indonesia, disamping mempunyai postur tubuh yang besar sebagai tipe domba pedaging (Isbandi, 2013).

Sebagian besar wilayah kelurahan $(76 \%)$ dimanfaatkan sebagai ladang dengan tanaman sayuran (caisin, wortel, tomat) dan tanaman perebunan 
(cengkeh, kopi, apokat). Sayur-sayuran umumnya ditanam di dataran tinggi seperti kampung Cinyurup. suatu kegiatan tanpa dampak yang tidak dapat diterima (Nautilus Consultants, 2000).

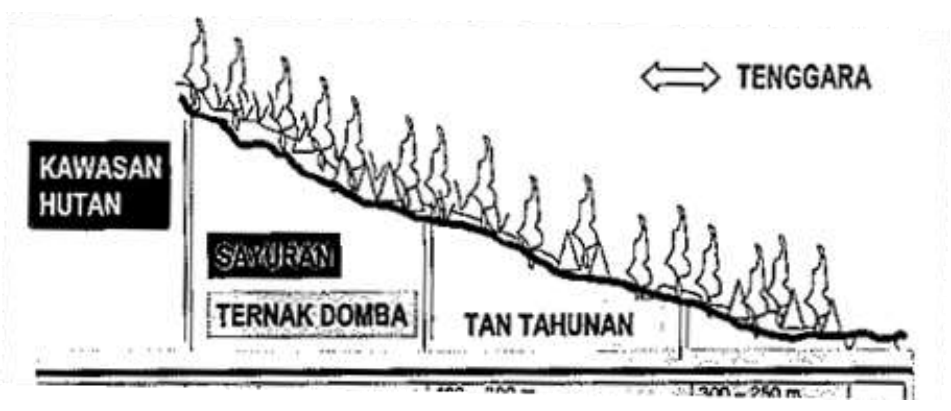

\begin{tabular}{|c|c|c|c|c|}
\hline Ketinggian & $700-400 \mathrm{~m}$ & $400-300 \mathrm{~m}$ & $300-250 \mathrm{~m}$ & \\
\hline \multirow[t]{5}{*}{ Kampung } & Cinyurup & Cangkoang & Kadu Limus & \\
\hline & Sanin & & Kadu Salak & \\
\hline & Ciodeng & & Juhut & \\
\hline & Balangenong & & Dalamaki & \\
\hline & Kadukupa & & Mauk & \\
\hline \multirow[t]{8}{*}{ Vegetasi } & Sayuran & Cengkeh & Cengkeh & \\
\hline & Cengkeh & Kopi & Pisang & \\
\hline & Kopi & Pisang & Sengon & JALAN \\
\hline & Melinjo & Kelapa & Durian & PROPINSI \\
\hline & Sengon & Padi (10ha) & Padi (20ha) & \\
\hline & Avokat & Melinjo & & \\
\hline & Jengkol & Jengkol & & \\
\hline & Pisang & Pete & & \\
\hline Pop Penduduk & Padat & Sedang & Padat & \\
\hline \multirow[t]{3}{*}{ Pek. Penduduk } & Tani $(90 \%)$ & Tani $(20 \%)$ & Tani $(20 \%)$ & \\
\hline & Buruh Tani & Pedagang & Pegawai & \\
\hline & & Pegawai & Pedagang & \\
\hline Masalah & Modal Usaha & Mudal Usaha & Kurang Air & \\
\hline
\end{tabular}

\section{Gambar 3. Transek Biofisik Kelurahan Juhut}

Tanaman perekebunan berkembang merata di seluruh wilayah, sedangkan tanaman padi terdapat di dataran rendah kelurahan Juhut (Gambar 6). Tnaman pangan seperti jagung, kacang tanah, buncis, ubi jalar, ubi kayu menyebar di seluruh wilayah termasuk dataran tinggi. Ternak domba dipelihara di seluruh wilayah, tetapi domba paling banyak terdapat di dataran tinggi kampung Cinyurup, akrena pakan berupa rumput dan dedauanan dari tanaman hutan tersedia cukup melimpah.

\section{Daya Dukung Lingkungan dalam Pengembangan PI-UMKM Peternakan Domba dan Kambing}

Pusat inovasi adalah suatu organisasi atau unit organisasi sebagai simpul, hubungan atau gateway dari jaringan kemitraan yang memberikan jasa pelayanan terpadu untuk menumbuh kembangkan UMKM yang inovatif. Untuk pengembangan PI UMKM tersebut dibutuhkan daya dukung lingkungan.

Daya dukung merupakan istilah yang lebih umum untuk karakter lingkungan dan kemampuannya dalam mengakomodasi suatu kegiatan tertentu atau laju
Daya dukung lingkungan adalah kemampuana lingkungan untuk mendukung perikehidupan manusia dan makhluk hidup lainnya (Soemarwoto, 1997). Bila dikaitkan dengan PI UMKM, daya dukung lingkungan diartikan dengan kemampuana lingkungan untuk mendukung pengembangan pusat inovasi UMKM. Daya dukung lingkungan PI UMKM meliputi layanan teknologi, pengembangan sumber daya manusia (SDM), intermediasi bisnis, inkubasi bisnis, akses informasi bisnis, dan fasilitasi.

Secara keseluruhan variabel daya dukung lingkungan untuk pengembangan PI UMKM Dombing Juhut adalah cukup, seperti terlihat pada Tabel 4.

Kriteria DDL yang cukup menunjukkan bahwa peternakan domba-kambing berpotensi untuk dikembangkan menjadi PI-UMKM. Bila sebelum perlakuan pengembangan program sudah menunjukkan DDL yang cukup, maka bila dikembangkan lebih lanjut akan berpotensi besar menjadi PI-UMKM yang maju sehingga dapat mendongkrak peternakan dombakambing di kelurahan Juhut khususnya, dan di Provinsi Banten pada umumnya. 
Proporsi variabel daya dukung lingkungan PIUMKM ditunjukkan oleh Gambar 4.

Didalam Gambar 4 menunjukkan bahwa variabel fasilitasi memiliki proporsi yang paling besar di antara kelima variabel DDL. Sedangkan akses informasi merupakan variabel dengan proporsi yang paling kecil. Hal ini menunjukkan bahwa fasilitasi menjadi modal utama dalam pengembangan PIUMKM. Sementara itu, akses informasi adalah variabel yang membutuhkan perhatian khusus untuk dikembangkan agar PI-UMKM bisa terwujud.

Variabel daya dukung lingkungan dalam pengembangan PI-UMKM secara rinci diuraikan sebagai berikut.
UMKM memiliki proporsi yang paling kecil.

Pada aspek akses informasi teknologi peternakan domba-kambing yang berkaitan dengan inseminasi buatan, teknologi pascapanen, teknologi pakan, dan teknologi penggemukan domba dan kambing telah tersedia. Lembaga yang menangani layanan tersebut adalah Dinas Peternakan dan Kesehatan Hewan Kab. Pandeglang dan Balai Pengkajian Teknologi Pertanian (BPTP Banten). Akan tetapi, informasi tentang hak kekayaan intelektual (HKI) yang berkaitan dengan peternakan belum ada karena lembaga HKI belum terbentuk. Oleh karena itu, pemerintah daerah melalui Balitbangda Prov. Banten dan Perguruan Tinggi perlu bersama-sama membentuk

Tabel 4. Kriteria DDL Pengembangan PI UMKM Dombing Juhut

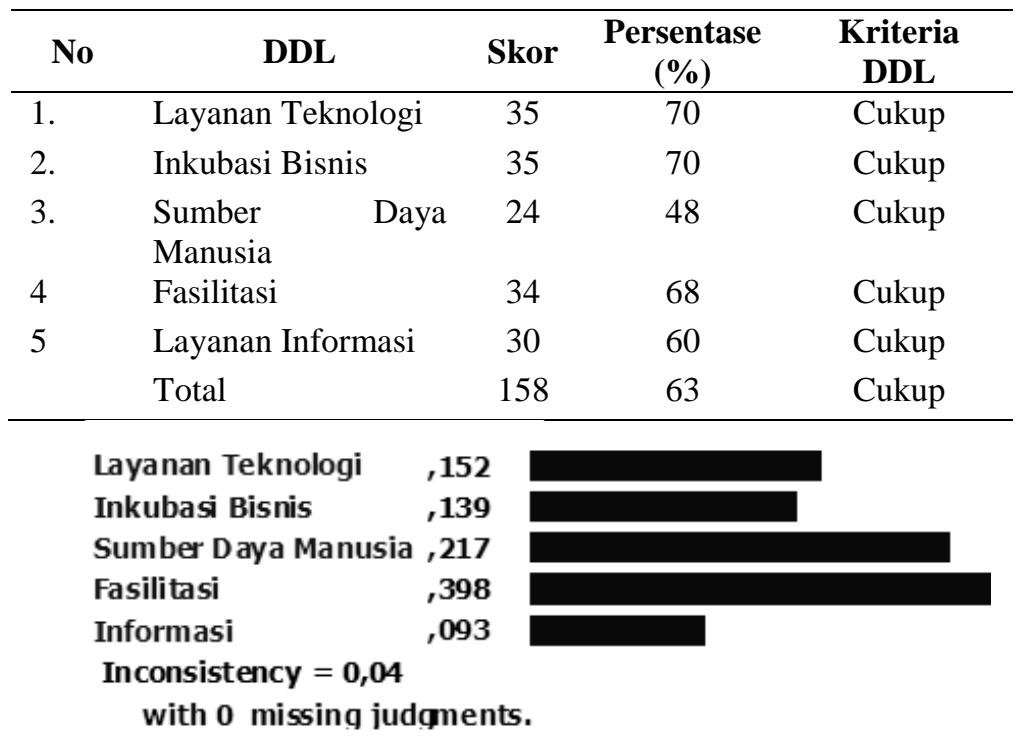

Gambar 4. Proporsi Variabel Daya Dukung Lingkungan

\section{PI-UMKM Peternakan Domba-Kambing}

\section{Daya Dukung Lingkungan Layanan Teknologi}

Daya dukung lingkungan layanan teknologi untuk pengembangan PI UMKM Domba-Kambing Juhut berdasarkan pandangan expert dapat dilihat pada Gambar 5.

Berdasarkan Gambar 5, layanan teknologi yang berupa akses informasi teknologi memliki proporsi yang paling besar $(0,289)$ Sementara itu, akses informasi HKI dan mempertemukan inventor dan lembaga sentra HKI.

Menurut Riswandi (2014), sentra HKI dapat dibentuk oleh Pemerintah, perusahaan swasta, BUMN, BUMD, koperasi, UKMK, Perguruan Tinggi, maupun perseorangan. Dengan demikian Sentra HKI di Propinsi Banten dapat dibentuk oleh pemerintah Provinsi Banten melaui Balitbangda, dan dapat juga dibentuk oleh perguruan tinggi seperti Untirta.

Pada aspek mempertemukan inventor (peneliti) dengan UMKM, Balitbangda harus mendorong dalam

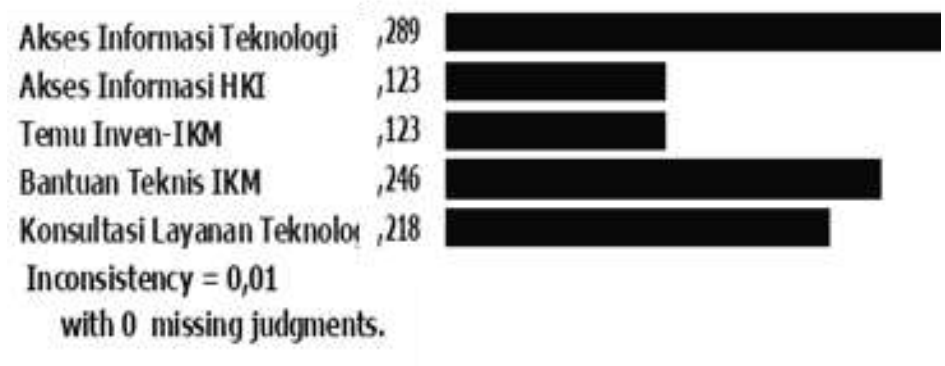

Gambar 5. Daya dukung lingkungan Layanan Teknologi

Kecil, dan Menengah (PI-UMKM) Peternakan Domba-Kambing di Kab. Pandeglang, Prov. Banten Muhlisin, Suroso Mukti, dan Devi Triady | 43 
memfasilitasi peneliti baik dari perguruan tinggi maupun dari BPTP untuk memberi informasi kepada UMKM.

Dinas Peternakan dan Kesehatan Hewan Kab. Pandeglang dan Balai Pengkajian Teknologi Pertanian (BPTP Banten), juga telah memberikan bantuan teknis: Pelatihan teknologi reproduksi, Penyuluhan penggemukan kambing, kesehatan ternak, teknologi pascapanen dan pelayanan konsultasi tentang teknologi yang berkaitan dengan peternakan domba-kambing.

Dengan demikian pada aspek layanan teknologi sudah dapat memenuhi untuk pengembangan PIUMKM peternakan domba-kambing.

\section{Daya Dukung Lingkungan Inkubasi Bisnis}

Daya dukung lingkungan inkubasi bisnis untuk pengembangan PI UMKM Dombing Juhut berdasarkan pandangan expert dapat dilihat pada Gambar 6.
Dengan demikian, walaupun inkubator bisnis belum terbentuk, namun potensi untuk pendirian inkubator bisnis tersebut cukup besar dengan sokongan dari Balitbangda porvinsi Banten, Bappeda, Dinas terkait Kab. Pandeglang dan Prov. Banten, BPTP, dan perguruan tinggi. Hal ini sejalan dengan saran Kemenkop UKM (2014), yang menyatakan bahwa pembentukan majelis inkubator untuk pembentukan lembaga inkubator bisnis di perguruan tinggi, yang terdiri dari: 1) Rektor Perguruan Tinggi, 2) Kepala LPPM Perguruan Tinggi, 3) Kepala Dinas pemerintah daerah yang membidangi kegiatan yang berhubungan dengan inkubator bisnis dan UKM, 4) Ketua KADIN, dan 5) Sektor swasta yang berminat.

Menurut Supriyadi \& Setiajatnika (2004), inkubator bisnis sebagai suatu lembaga pembinaan UMKM dapat menjadi jembatan dan mediasi proses adopsi, adaptasi, dan alih teknologi dan produk-produk

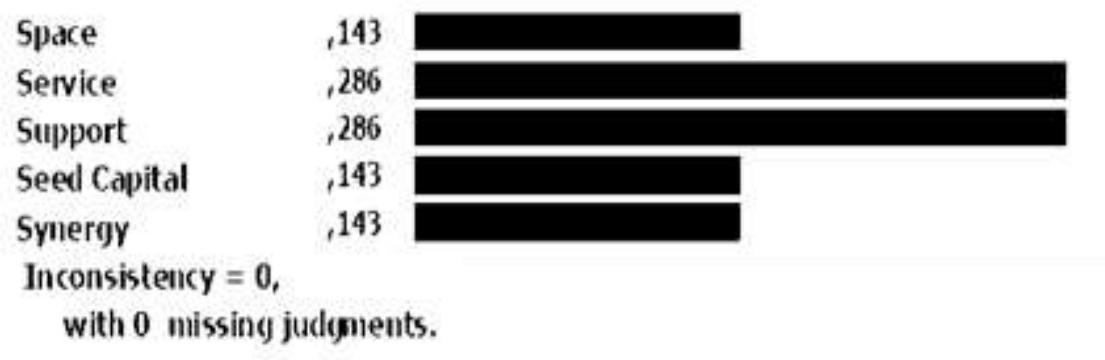

\section{Gambar 6. Daya dukung lingkungan Inkubasi Bisnis}

Berdasarkan Gambar 6, diketahui bahwa aspek service (bimbingan dan konsultasi manajemen: pemasaran, pembiayaan, produksi, teknologi dan sebagainya) dan support (bantuan dukungan penelitian dan pengembangan usaha dan akses penggunaan teknologi) memliki proporsi yang paling besar $(0,286)$. Sedangkan sisanya, yaitu: space (penyediaan sarana perkantoran yang bisa dipakai bersama. Misalnya sarana fax, telepon, foto copy, ruang rapat, komputer dan sekretariat), seed capital (penyediaan dana awal usaha serta upaya memperoleh akses permodalan kepada lembaga-lembaga keuangan), dan sinergy (penciptaan jaringan usaha baik antar usaha baik usaha lokal maupun internasional) memiliki proporsi yang lebih rendah $(0,143)$.

Perguruan Tinggi, Swasta (konsorsium), Balitbangda, Bapeda bersedia menyediakan ruangan kantor dan perlengkapannya untuk sekretariat inkubator bisnis. Perguruan Tinggi dan penyuluh juga bersedia memberikan bimbingan dan konsultasi mengenai bisnis dan marketing peternakan dombakambing sedangkan penyuluh dan Disnakkeswan bersedia memberikan dukungan dan pengembangan usaha dan akses penggunaan teknologi mengenai peternakan domba-kambing.

Akses penyedian dana awal, dan upaya memperoleh akses permodalan kepada lembagalembaga keuangan dapat difasilitasi oleh Dinas Koperasi dan UMKM serta Bank). Dinas Koperasi Propinsi Banten juga dapat membantu menciptakan jaringan antar usaha, lokal maupun internasional. riset. Peran ini dilakukan lewat berbagai kegiatan pendampingan, konsultasi, dan fasilitasi teknologi dan produk riset yang berlangsung simultan dengan kegiatan yang sama dalam aspek manajerial dan kemampuan kewirausahaan.

Inkubator dan lembaga riset dapat melakukan perencanaan dan operasi secara kolaboratif terhadap proses alih teknologi dan penggunaan produk riset. Perencanaan dan operasi kolaboratif ditujukan untuk mengefektifkan proses alih teknologi dari sumber riset dan teknologi kepada pengusaha binaan inkubator bisnis sebagai pengguna dengan memperhatikan pula aspek kultur dan perilaku sasaran. Proses mediasi pengembangan kewirausahaan dan transfer teknologi.

Untuk mewujudkan inkubator bisnis dilakukan melalui langkah-langkah sebagai berikut (Smecda.com, 2014)

1. Pengintaian awal / orientasi untuk konsep inkubator bisnis,

2. Pembentukan dari komite nasional,

3. Perumusan proyek,

4. Merekrut dan menseleksi konsultan,

5. Persiapan studi kelayakan,

6. Pemilihan lokasi,

7. Rencana fasilitas,

8. Analisis pasar dan rencana pasar,

9. Rencana pendukung layanan/ services,

10. Rencana pembelanjaan,

11. Rencana organisasi dan managemen,

12. Rencana bisnis, 
13. Tinjauan dan penyelesaian pelapor konsep/ naskah, studi kelayakan, dan Perencanaan bisnis,

14. Pengabungan yang sah,

15. Mengumpulkan dana,

16. Pelatihan calon manajer inkubator,

17. Pelatihan calon pengusaha/ tenant inkubator teknologi,

18. Peluncuran proyek, dan

19. Mendirikan perusahaan pembelanjaan tenant.

\section{Daya Dukung Lingkungan Sumber Daya Manusia}

Daya dukung lingkungan sumber daya manusia untuk pengembangan PI UMKM Dombing Juhut berdasarkan pandangan expert dapat dilihat pada Gambar 7. yaitu: bidang teknologi pakan, bidang industri pembibitan dan bidang pemasaran;

3. Pihak lembaga pendidikan tinggi peternakan perlu meningkatkan profesionalisme lulusan (sarjana peter-nakan) sesuai dengan kebutuhan pasar kerja (perbaikan kualitas lulusan) sehingga mampu membangun industri peternakan yang berdaya saing.

\section{Daya Dukung Lingkungan Fasilitasi}

Daya dukung lingkungan fasilitasi untuk pengembangan PI UMKM Dombing Juhut berdasarkan pandangan expert dapat dilihat pada Gambar 8.

Berdasarkan Gambar 8 diketahui aspek informasi sumber biaya, menghubungkan IKM dengan

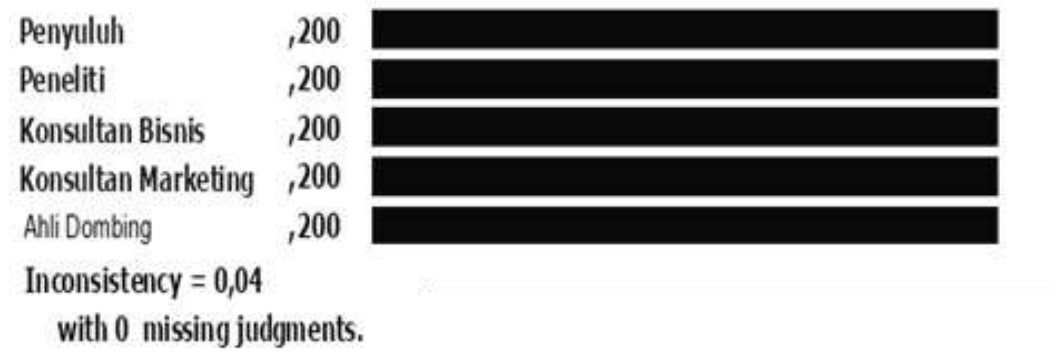

Gambar 7. Daya Dukung Lingkungan Sumber Daya Manusia

\begin{tabular}{|l|}
\hline Info sumber Biaya \\
\hline Hu bungkan IKM-Sumber Biaya \\
\hline Alses Info Pasa \\
\hline Klinik Bisnis \\
\hline Promo Produk IKM \\
\hline In onsistency = 0, \\
\hline with 0 missing judgments. \\
\hline \multicolumn{2}{|c|}{ Gambar 8. Daya dukung lingkungan Fasilitasi } \\
\hline
\end{tabular}

Sumber daya manusia untuk pengembangan PI UMKM Dombing Juhut telah cukup terpenuhi. Tenaga penyuluh peternakan domba kambing sudah tersedia, begitu pula dengan peneliti yang berkaitan dengan peternakan domba kambing di BPTP. Di Beberapa Perguruan Tinggi juga telah terdapat ahli bidang bisnis, ahli marketing dan ahli bidang teknologi yang berkaitan dengan peternakan domba kambing.

Dengan demikian, variabel sumber daya manusia mendukung penuh pengembangan PI-UMKM peternakan domba-kambing dengan proporsi yang seimbang.

Sarengat dkk. (2014), menyatakan bahwa strategi pemberdayaan SDM peternakan yaitu dengan mendorong dukungan dari pihak-pihak terkait antara lain:

1. Pihak pemerintah, perlu mendorong tumbuhnya investasi dalam negeri di

bidang industri peternakan, dari segmen hulu sampai hilir;

2. Pihak swasta pelaku industri peternakan perlu memfasilitasi kegiatan penelitian dan pengembangan $(\mathrm{R} \& \mathrm{D})$, pada tiga ranah $\mathrm{R} \& \mathrm{D}$, sumber biaya, akses informasi pasar, dan promo produk IKM memiliki proporsi yang sama $(0,222)$, kecuali pada aspek Klinik Bisnis memiliki proporsi yang lebih rendah $(0,111)$

Dinas Koperasi dan UMKM, CSR dan Bank Indonesia telah memberikan informasi mengenai sumber-sumber pembiayaan, menghubungkan UMKM dengan sumber-sumber pembiayaan, memberikan akses informasi mengenai pasar yang berkaitan dengan peternakan domba-kambing. Sedangkan Perguruan Tinggi bersedia memfasilitasi pendirian klinik konsultasi bisnis yang berkaitan dengan fasilitas, SDM, materi untuk konsultasi bisnis. Dinas Koperasi juga bersedia melakukan promo produk UMKM domba dan kambing berupa pameran dan promosi produk.

Dengan demikian, dari aspek fasilitasi juga dapat mendukung pengembangan PI-UMKM peternakan domba-kambing, bahkan dengan proporsi yang paling tnggi dibandingkan dengan keempat variabel lainnya.

Untuk mendirikan klnik bisnis Rhisiart, dkk. (2000) mengungkapkan ada tiga tahap: Tahap persiapan, Tahap klinik, dan tahap Implementasi. Pada tahap persiapan, perlu mengidentifikasi isu-isu dan 
spesifikasi klinik. Sedangkan pada tahap klinik, dilakukan hubungan dengan pemamngku bisnis atau perorangan melalui seminar atau hubungan individu. Pada tahap implementasi, klinik bisnis membuat kesepakatan dengan kelompok perusahaan untuk melakukan kegiatan pendampingan.

\section{Daya Dukung Lingkungan Akses Informasi}

Daya dukung lingkungan akses informasi untuk pengembangan PI UMKM Dombing Juhut berdasarkan pandangan expert dapat dilihat pada Gambar 9.

Berdasarkan Gambar 9 diketahui bahwa aspek layanan informasi dan sumber informasi memiliki proporsi paling besar $(0,286)$ di bandingkan ketiga aspek lainnya, yaitu: publikasi, website, dan android $(0,143)$.

Akses informasi dapat diperoleh dari Buletin/jurnal atau media lainnya yang berkaitan dengan peternakan domba/kambing yag tersedia di basis data dan perpustakaan. Selain itu pemerintah domba dan kambing di Juhut. Oleh sebab itu dianalisis juga daya dukung lingkungan dalam pengembangan peternakan domba dan kambing, yang meliputi daya dukung fisik, sosial ekonomi dan ekologi. Hasil analisis daya dukung pengembangan peternakan domba dan kambing Juhud dapat dilihat pada Tabel 5.

Tabel 5. Kriteria DDL Peternakan Domba dan Kambing

Kelurahan Juhut Pandeglang

\begin{tabular}{ccccc}
\hline No. & DDL & Skor & $\begin{array}{c}\text { Persentase } \\
(\boldsymbol{\%})\end{array}$ & Kriteria \\
\hline 1. & Fisik & 48 & 96 & Baik \\
2. & $\begin{array}{l}\text { Sosial } \\
\text { Ekonomi }\end{array}$ & 43 & 86 & Baik \\
3. & Ekologis & 41 & 82 & Baik \\
\hline
\end{tabular}

Semua kriteria Daya Dukung lingkungan

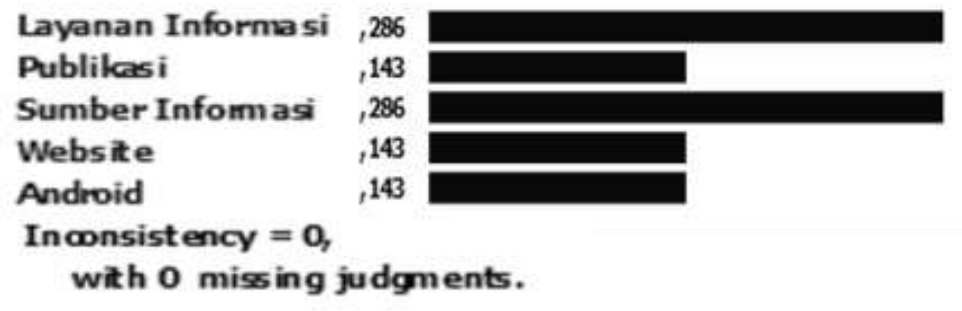

Gambar 9. Daya Dukung Lingkungan Akses Informasi

daerah juga telah memiliki akun FB/tweeter/website yang berkaitan peternakan domba/kambing. Fasilitas informasi yang berkaitan dengan peternakan domba/kambing berbasis android juga telah tersedia di playstore android yang dibuat oleh Balitbangda Prov. Banten.

Hasil penelitian Rahman (2009) menunjukkan bahwa UKM perlu memanfaatkan TI untuk meningkatkan daya saingnya, mengingat di era globalisasi ini arena persaingan semakin kompetitif, dan bersifat mendunia. Dengan pemanfaatan TI akan mendorong UKM untuk mendapatkan peluang ekspor dan peluang bisnis lainnya. Sejalan dengan hal tersebut Adeosun, et al (2009) juga berpendapat bahwa penggunaan TI memberikan nilai positif bagi strategi manajemen yang terkait dengan aspek komunikasi, akses informasi, pengambilan keputusan, manajemen data dan knowledge management pada sebuah organisasi. TI dapat menjadi kekuatan strategi dan alat bagi organisasi yang memberikan keuntungan pada aspek promosi dan kekuatan daya saing (Supriyadi \& Setiajatnika, 2014). Oleh karena itu teknologi informasi penting sekali peranannya dalam pengembangan PI-UMKM Peternakan DombaKambing di Provinsi Banten.

\footnotetext{
Daya Dukung Lingkungan Fisik, Sosial Ekonomi, dan Ekologis

Pengambangn PI UMKM juga harus didukung oleh kesiapan pengembangan peternakan
}

fisik, sosial ekonomi dan ekologi dalam pengembangan peternakan domba dan kambing dalam kategori baik. Berarti lingkungan fisik, sosial ekonomi, dan ekologi di kelurahan Juhut sesuai untuk pengembangan peternakan domba dan kambing.

Daya dukung lingkungan fisik sudah terdapat aspek jalan yang memadai (jalan aspal dan lancar), sumber listrik: terdapat listrik PLN, namun belum ada sumber tenaga listrik yang lain. Di kelurahan Juhut bisa dikembangkan pembangkit listrik tenaga surya, PLTA, dan lain-lain bila diperlukan.

Di kelurahan juhut juga sudah terdapat air bersih, yang berasal dari mata air dan terdapat aliran drainase/sungai. Selain itu faktor fisik juga ditunjang oleh kelancaran telekomunikasi baik berupa: email, web, surat, dan telefon genggam (hp).

Daya dukung sosial ekonomi terlihat dari tersedianya tenaga kerja. Penduduk sekitar sebagian besar bekerja sebagai petani, buruh, peternak. Warga sekitar juga mendukung dikembangkannya peternakan domba dan kambing. Faktor lainnya adalah sudah terdapat Kelompok tani (kelompok tani pertanian, peternakan, perkebunan) sehingga mendukung lingkungan dalam peternakan domba dan kambing.

Daya dukung ekologi dalam pengembangan peternakan domba dan kambing tercermin dari adanya penggunaan lahan yang terencana (tata ruang direncanakan, lahan untuk peternakan, kandang, makanan ternak dan perkebunan), adanya pasokan air (ada pasokan air untuk rumah tangga, peternakan dan 
pertanian), adanya ketersediaan pakan (ada pakan hijau, sisa hasil pertanian, ampas singkong), tersedianya kandang (terdapat kandang semi permanen, kandang dibuat jauh dari pemukiman, kandang jantan dan betina dipisah, kandang dibuat panggung) dan terdapat layanan kesehatan hewan (terdapat penyuluh dan puskeswan).

Proporsi daya dukung lingkungan fisik, sosial ekonomi, dan ekologis dapat dilihat pada Gambar 10.
Peternakan domba-kambing di Provinsi Banten cukup memadai untuk dibentuk dan dikembangkan.

Daya dukung lingkungan fisik, sosial ekonomi, dan ekologis memiliki katagori baik. Artinya lingkungan di Kelurahan Juhut mendukung pengembangan peternakan domba-kambing secara berkelanjutan.

Daya dukung lingkungan PI-UMKM yang paling tinggi adalah fasilitasi, dan variabel yang paling rendah adalah akses informasi. Aspek Fasilitasi

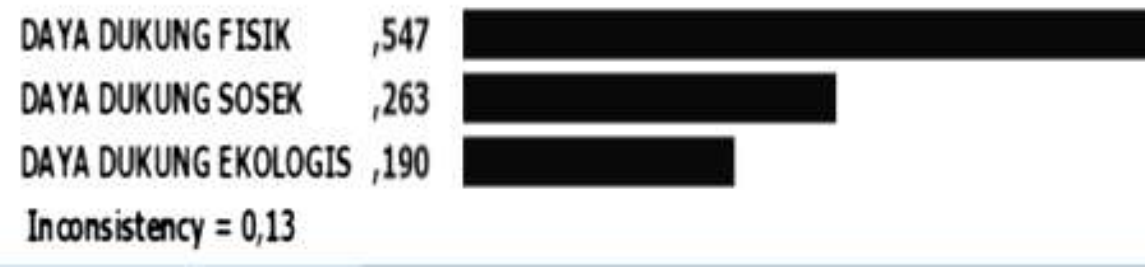

\section{Gambar 10. Daya Dukung Lingkungan Fisik, Sosial Ekonomi dan Ekologi Dalam Pengembangan Peternakan Domba dan Kambing}

Berdasarkan Gambar 10, diketahui bahwa daya dukung lingkungan fisik memiliki proporsi yang paling besar $(0,547)$. Sedangkan proporsi yang paling kecil dimiliki oleh daya dukung lingkungan ekologis $(0,190)$

Soemarwoto (1997) mendefinisikan bahwa daya dukung menunjukkan besarnya kemampuan lingkungan untuk mendukung kehidupan hewan yang dinyatakan dalam jumlah ekor per satuan luas lahan. Jumlah hewan yang dapat didukung kehidupannya itu tergantung pada biomas yang tersedia untuk makanan hewan. Dengan demikian daya dukung dapat dibedakan dalam beberapa tingkat, yakni daya dukung maksimum, daya dukung subsisten, daya dukung optimum dan daya dukung sub optimum.

Berdasarkan penjelasan tersebut. Daya dukung lingkungan peternakan domba-kambing di kelurahan Juhut termasuk katagori tinggi, Karena sarana prasaran peternakan masih tersedia melimpah, sementara jumlah ternak domba-kambing belum banyak.

Kesiapan lembaga dalam mendukung pengembangan PI UMKM Dombing Juhut dapat dilihat pada Gambar 11.

Didalam Gambar 11 menunjukkan bahwa, perguruan tinggi unggul dalam mendukung pengembangan PI-UMKM pada variabel inkubasi bisnis, akses informasi, dan secara keseluruhan (overall). Sementara itu, Pemprov Banten unggul pada variabel layanan teknologi dan fasilitasi. Namun demikian, Upaya yang sinergis antara Pemprov. Banten, Pemkab, Pandeglang, BPTP, an Perguruan tinggi akan mempercepat terlaksananya pembentukan PI-UMKM peternakan domba-kambing.

\section{KESIMPULAN}

Berdasarkan hasil penelitian dan pembahasan dapat disimpulkan hal-hal sebagai berikut.

Tingkatan daya dukung lingkungan PI-UMKM berada pada katagori cukup. Artinya PI-UMKM menjadi modal utama dalam pengembangan PIUMKM peternakan domba-kambing. Sementara aspek yang lain terus dipacu untuk dikembangkan.

Strategi pengembangan PI-UMKM peternakan domba-kambing di Provinsi Banten adalah melalui upaya peningkataan variabel-variabel DDL PI-UMKM yang masih kurang atau belum memenuhi melalui usaha sinergi Pemrov. Banten, Pemkab/Pemkot, BPTP, dan Perguruan Tinggi.

Rekomendasi dari hasil kajian tersebut adalah sebagai berikut.

PI-UMKM peternakan domba-kambing di Provinsi Banten berpotensi besar dibentuk untuk peningkatan daya saing penyediaan daging ternak serta produk olahannya di Provinsi Banten.

Pembentukan PI-UMKM peternakan dombakambing harus melibatkan beberapa unsur, seperti: Pemprov. Banten, Pemkab. Pandeglang, BPTP, Perguruan Tingi, Bank Indonesia, dan Swasta lainnya. 


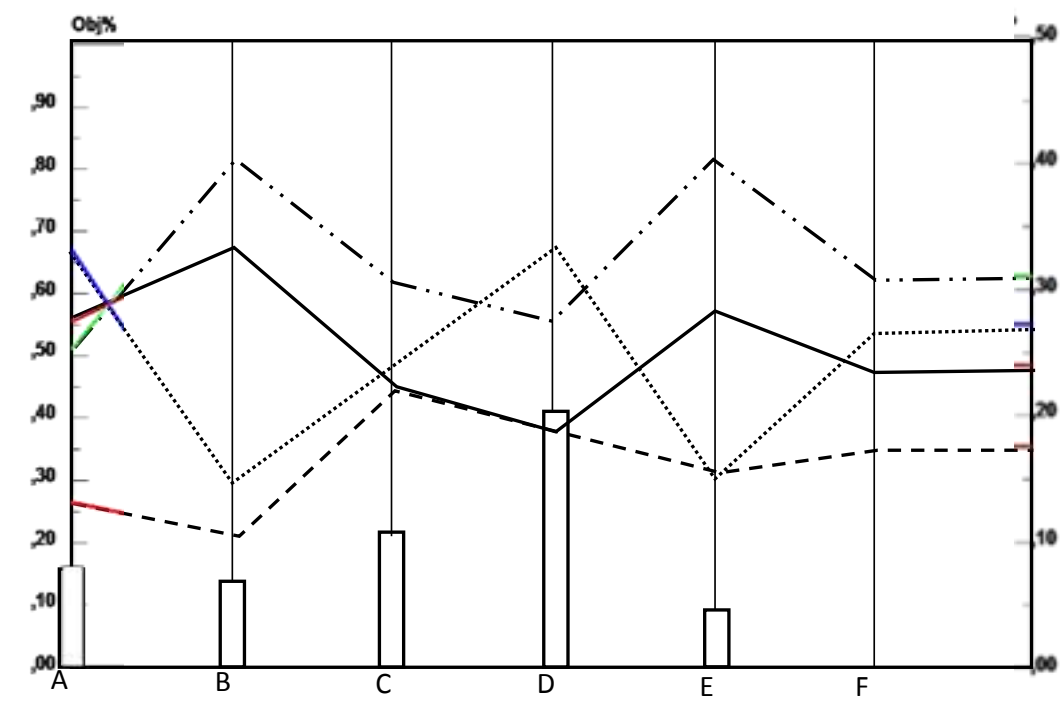
Keterangan:
A. Layanan Teknologi $\quad$ D. Fasilitasi
B. Inkubasi Bisnis E. Akses Informasi
C. Sumber Daya Manusia F. OVERALL
- - - Perguruan Tingg
....... Pemprov Banten
- BPTP
- - Pemkab Pandeglang

\section{Gambar 11. Kesiapan Lembaga dalam Mendukung Pengembangan PI UMKM Dombning Juhut}

\section{Daftar Pustaka}

Adeosun, O., Adeosun, T.H., and Adetunde, I.A. 2009. Strategic Application of Information and Communication Technology for Effective Service Delivery in Banking Industry. Journal of Social Science, 5(1): 47-51.

Balitnak (=Balai Penelitian Ternak). 2011. Kisah Sukses

Kampung Domba Terpadu.

http://balitnak.litbang.pertanian.go. id/ index.php?option=com_content \&view $=$ article\&id $=54:$ terpadu\&catid $=65: \mathrm{mjlh}$

Isbandi. 2013. Pembentukan Kampung Ternak Domba Sebagai Upaya Mendekatkan Teknologi Peternakan Kepada Masyarakat. Wartazoa, 23(3): $115-121$.

Irwan, Z.D. 1997, Tatanan Lingkungan dan Lansekap Hutan Kota. Jakarta: CIDES.

Kemenkop UKM (=Kementerian Koperasi Dan Usaha Kecil dan Menengah Republik Indonesia). 2014. Pedoman Pendirian dan Pengelolaan Inkubator Bisnis Perguruan Tinggi. Jakarta: Deputi Bidang Pengembangan Dan Restrukturisasi Usaha

Nautilus Consultants. 2000. Planning for Coastal Aquaculture Development, A Training Course Handbook. www.nautilus-consultants.co.uk., Oktober 2014

Oktaviana, O., dan D.T., Bachrudin,. 2014. Kajian Pengembangan Pusat Inovasi UMKM, Pusat Unggulan IPTEK Spesifikasi Daerah dan Desa Inovatif. Serang: Badan Peneitian dan Pengembangan Daerah Provinsi Banten.
Prayitno, D., W. Puastuti, \& B.R. Prawuradiputra. 2009. Analisis Potensi Pengembangan Domba di Kelurahan Juhut, Kecamatan Karang Tanjung, Kabupaten Pandeglang, Provinsi Banten (melalui Pendekatan Participatory Rural Appraisal). Balai Penelitian Ternak, Badan Penelitian dan Pengembangan Pertanian, Departemen Pertanian.

Rahman. A. 2009. Peranan Teknologi Informasi Dalam Peningkatan Daya Saing Usaha Kecil Menengah. Yogyakarta: Seminar Nasional Aplikasi Teknologi Informasi 20 Juni 2009 (SNATI 2009) ISSN: 1907-5022

Riswandi. 2014. Pengelolaan Kekayaan Intelektual dan Hak Kekayaan Intelektual di Perguruan Tinggi (PT).

http://dppm.uii.ac.id/dokumen/workshop/BUDI_A GUS_RISWANDI-

PENGELOLAAN\% 20KEKAYAAN\%20INTELE KTUAL\%20DAN\%20HAK\%20KEKAYAAN\%2 OINTELEKTUAL\%20DI.ppt

Rhisiart, M., G. Roberts, \& M. Thomas. 2000. Technology Clinics. Observatory of Innovation \& Business Development Cardiff Business School. http://www.adi.pt/docs/innoregio_techn_clinicsn.p df

Saaty. T. L., 1993, Pengambilan Keputusan Bagi Para Pemimpin, Jakarta: .PT Pustaka Binaman Pressindo.

Sarengat, W., Achmadi, J., \& Eddy, B.T. 2014. Pemberdayaan Sumberdaya Manusia Peternakan Menuju Usaha Ternak Unggas Yang Berdaya Saing. Lokakarya Nasional Inovasi Teknologi Dalam Mendukung Usahaternak Unggas 
Berdayasaing Semarang: Fakultas Peternakan Universitas Diponegoro.

Sinar Tani. 2011. Model "Kampoeng Ternak Domba" Mengarah Pada Pengembangan "Village Breeding Centre" Sebagai Salah Satu Wahana Diseminasi Balai Penelitian Ternak. Balai Penelitian dan Pengembangan Pertanian, Edisi 14-20 Desember 2011 No.3435 Tahun XLII

Smecda.com. 2014. http://www.smecda. com/ Modul_Pelatihan/Inkubator/ INKUBATOR\%20TEKNOLOGI.pdf. Diakses 2 November 2014.

Soemarwoto, O., 1997. Ekologi, Lingkungan Hidup Pembangunan, Jakarta: Djambatan.

Subagjo, I. 2011. Pengembangan Pusat Inovasi Usaha Mikro, Kecil dan Menengah (PI UMKM) dalam Kerangka Sistem Inovasi Daerah (SIDa). http://ejurnal.bppt.go.id/index.php/JSI/article/view 15. Diakses tanggal 7 April 2014.
Supriyadi, R.E, dan Setiajatnika, E. 2014. Inkubator Sebagai Media Transfer Teknologi dan Pengembangan Kewirausahaan. http://www.stanim.ac.id/jsma/pdf/vol1/INKUBATOR\%20SEBAG AI\%20MEDIA\%20TRANSFER\%20\%20TEKNO LOGI\%20DAN\%20PEGEMBANGAN\%20KEWI RAUSAHAAN.pdf. Diakses 2 November 2014

Susilo, S. 2010. Strategi Meningkatkan Daya Saing UMKM Dalam Menghadapi Implementasi CAFTA Dan MEA. Yogyakarta: Atma Jaya.

Taufik,T.A. 2013. Contoh Implementasi Penguatan Sistem Inovasi Di Beberapa Kabupaten/Kota. Paparan Workshop DRN-DRD "Penguatan Sumberdaya, Kelembagaan, dan Jaringan Iptek Pusat dan Daerah Untuk Peningkatan Daya Saing dan Kemandirian Bangsa" Jakarta: BPPT.

Undang-Undang Republik Indonesia Nomor 23 Tahun 2000 Tentang Pembentukan Propinsi Banten.

Undang-Undang Republik Indonesia Nomor 32 Tahun 2004. Tentang otonomi daerah

Daya Dukung Lingkungan dalam Pengembangan Pusat Inovasi Usaha Mikro, 
50 | Jurnal Bina Praja | Volume 7 Nomor 1 Edisi Maret 2015 : 37 - 50 